\title{
РЕГЛАМЕНТАЦИЯ МЕР УГОЛОВНО-ПРОЦЕССУАЛЬНОГО ПРИНУЖДЕНИЯ В НОВОМ УПК РЕСПУБЛИКИ КАЗАХСТАН: СРАВНИТЕЛЬНО-ПРАВОВОЙ АНАЛИЗ
}

\begin{abstract}
Аннотация: Статья преследует цель раскрытия основных новелл в регулировании мер уголовно-процессуального принуждения нормами Уголовно-проиессуального кодекса Республики Казахстан, вступивщего в силу с 1 января 2015 года в контексте необходимости изучения зарубежного опыта при разработке перспективных направлений совершенствования института мер уголовно-процессуального принуждения в современном уголовном процессе России. До 1 января 2015 года в Республике Казахстан действовал Уголовно-процессуальный кодекс, принятьій в 1997 году и, несмотря на отдельные специфические нормы, являвиийся продолжателем традиций советского уголовного прочесса. Значительный шаг в реформировании института мер уголовно-процессуального принуждения в Казахстане был сделан в 2014 году в связи с принятием нового УПК, в котором был учтен опыт различных государств, в том числе и России. Регламентация института мер процессуального принуждения в УПК Казахстана осуществлена детально, но в ряде случаев противоречиво. Исследование регламентации мер процессуального принуждения в Республике Казахстан осуществлено с применением сравнительно-правового, системно-структурного и структурно-функиионального методов исследования. Использование совокупности этих методов позволило раскрыть закономерности произошедших изменений в уголовно-процессуальном законодательстве Казахстана с позиций их полезности для российского законодателя. В статье институт мер процессуального принуждения в уголовном судопроизводстве Казахстана автором рассматривается как система проиессуально-принудительных средств обеспечения его надлежащего порядка, традиционно состоящей из трех элементов: задержания подозреваемого, мер пресечения и иных мер прочессуального принуждения. Для каждого элемента этой системь были выделены специфические черты, характеризующие особенности данной меры прочессуального принуждения при производстве по уголовным делам в сравнении с аналогичными мерами российского уголовного судопроизводства. В результате исследования были сформулированы положения, позволяющие критически переработав нормы УПК Казахстана адаптировать их для российских реалий.
\end{abstract}

Ключевые слова: Сравнительно-правовой метод, меры процессуального принуждения, задержание подозреваемого, меры пресечения, залог, домашний арест, содержание под стажей, доставление, criminal proceеdings, уголовное судопроизводство.

Abstract: The article attempts to reveal the main novelties in the regulation of measures in criminal-procedural compulsion using the norms of the Criminal Procedure Code of the Republic of Kazakhstan (CPCRK) effective January 1, 2015 in the context of the need to study foreign experience in devising prospective vectors for improving the institution of the measures of criminal-procedural compulsion in the modern criminal procedure of the Russian Federation. Prior to January 1 st of 2015, the Republic of Kazakhstan used the Criminal Procedure Code of 1997, which with the exception of a few specific norms represented the continuation of the traditions of the Soviet criminal procedure. A significant step towards reform of the institution of measures of criminal-procedural compulsion in Kazakhstan was made in 2014 due to introduction of the new Criminal Procedure Code, which borrowed from the experience of various countries, including Russia. Regulation of this institution in Kazakhstan is very detailed, but in many cases controversial. As a result of the conducted research, the author formulates positions that would allow adopting the norms of the CPCRK in Russia after being critically reworked. Keywords: House arrest, bail, preventive measure, detention of a suspect, measures of procedural compulsion, comparative legal method, custody, delivery, Criminal Procedure Code of Kazakhstan, criminal proceedings.

июля 2014 года был принят Уголовно-процессуальный кодекс Республики Казахстан (далее - УПК Казахстана 2014 г.), который вступил в силу с изменениями и дополнениями, внесенными Законами Республики Казахстан от 29.09.2014 г. №239$\mathrm{V}$ и от 07.11.2014 г. №248-V, с 1 января 2015 года [1].
Примечательным является тот факт, что в Республике Казахстан это уже второй УПК, принятый в постсоветский период. Первый УПК Республики Казахстан (далее - УПК Казахстана 1997 г.) был принят еще в 1997 году [2].

Так же как и прежде, в УПК Казахстана 2014 г. мерам процессуального принуждения отводится отдельный 
DOI: 10.7256/1811-9018.2015.6.15323

При цитировании этой статьи сноска на doi обязательна

Закон и правопорядок

раздел 4, в котором не содержится определения мер процессуального принуждения. Вместо этого, так же как и в УПК РФ, законодатель относит к ним задержание подозреваемого (глава 17), меры пресечения (глава 18) и иные меры процессуального принуждения (глава 19). Регламентации мерам процессуального принуждения в УПК Казахстана 2014 г. в общей сложности посвящено уже 38 статей (в прежнем УПК Казахстана 1997 г. их было 30). Для сравнения: в УПК РФ и того меньше-28 [3]. Прирост количества статей произошел следующим образом: глава 17 «Задержание подозреваемого» пополнилась 1 статьей, глава 18 «Меры пресечения» - 2, глава 19 «Иные меры процессуального принуждения» - сразу 5 статьями.

Регламентация задержания подозреваемого в УПК Казахстана 2014 г. представляет значительный интерес для российского исследователя, поскольку имеет весьма интересные детали. Так, новеллой УПК Казахстана 2014 г. является то, что задержание подозреваемого применяется в различных целях в зависимости от формы досудебного расследования: при производстве предварительного следствия или дознания данная мера применяется в целях пресечения преступления и разрешения вопроса о применении к нему меры пресечения в виде содержания под стражей; при производстве досудебного расследования в протокольной форме по уголовным проступкам - для обеспечения этого производства, по которому имеются основания полагать, что лицо может скрыться либо совершить более тяжкое деяние (ст.128).

Характерной особенностью задержания подозреваемого по уголовно-процессуальному законодательству Казахстана отличается регламентация оснований задержания лица, подозреваемого в совершении преступления: во-первых, к таковым относится задержание лица очевидцами (свидетелями), в том числе потерпевшими в соответствии со ст.130 УПК Казахстана 2014 г.; во-вторых, в качестве самостоятельного основания для задержания лица предусматривается наличие в полученных в соответствии с законом материалах оперативно-розыскной деятельности и (или) негласных следственных действий в отношении лица достоверных данных о совершенном или готовящемся им преступлении (п.4 ч.2 ст.128).

Интересной новеллой УПК Казахстана 2014 г. является указание в ч. 3 ст.128 на обязательность производства необходимых неотложных следственных действий до задержания, кроме случаев задержания на месте преступления. В этой связи стоит отметить некоторое логическое несоответствие УПК Казахстана 2014 г., так как в его ст.196, перечисляющей эти неотложные следственные действия, включены также задер- жание и допрос подозреваемых. Таким образом, УПК Казахстана 2014 г. не до конца избавился от противоречия уголовного процесса советской эпохи по вопросу правовой природы самого задержания.

Срок задержания подозреваемого в Казахстане, в отличие от России, сохранил свою продолжительность в 72 часа с момента фактического задержания, на что обращают внимание ч. 5 ст. 128 и ч. 4 ст.131 УПК Казахстана 2014 г. В этой связи стоит положительно оценить п.29 ст.7 УПК Казахстана 2014 г., в котором содержится достаточно удачное разъяснение термина «фактическое задержание». Данное определение с одной стороны содержит детальное описание конкретных действий, направленных на ограничение личной свободы гражданина, с другой стороны перечень этих действий является открытым, а в довершении указывается, что данные действия будут считаться задержанием независимо от придания лицу какого-либо процессуального статуса или выполнения иных формальных процедур. Все это в совокупности, как представляется, упрощает применение уголовно-процессуальных норм практическими работниками, способствует их верному пониманию иными гражданами и снижает возможности для разного рода злоупотреблений со стороны недобросовестных сотрудников правоохранительных органов, получивших широкую огласку в средствах массовой информации [4].

Не является новеллой, но заслуживает отдельного рассмотрения ст.130 УПК Казахстана 2014 г. «Право граждан на непроцессуальное задержание лиц, совершивших уголовное правонарушение». Обращаясь к институту задержания подозреваемого в уголовном процессе России стоит обратить внимание на полное отсутствие аналогичной нормы в УПК РФ. Признать аналогичными по четкости регулирования по сути процессуальных отношений взаимосвязанные положения статей 37 и 38 Уголовного кодекса РФ [5], на наш взгляд, нельзя. В результате подобные пробелы генерируют на практике чрезвычайно негативные ситуации, влекущие существенные нарушения уголовно-процессуального законодательства и прав личности. Представляется совершенно обоснованным закрепить указанное право граждан России в УПК РФ.

Анализируя название ст.130 УПК Казахстана 2014 г. в сравнении с аналогичной статьей 133 УПК Казахстана 1997 г., следует признать несколько неудачной его новую редакцию, которое было дополнено словом «непроцессуальное». Думается, само закрепление в статье уголовно-процессуального закона такой разновидности задержания ставит под сомнение обоснованность применения к нему термина «непроцессуальное». 
DOI: $10.7256 / 1811-9018.2015 .6 .15323$

При цитировании этой статьи сноска на доі обязательна

\section{Право и политика 6 (186) • 2015}

Рассматривая следующую статью 131 УПК Казахстана 2014 г. «Порядок процессуального задержания лица, подозреваемого в совершении уголовного правонарушения» становится ясной логика законодателя, который, по всей видимости, стремился такой терминологической разницей разграничить задержание, осуществляемое органами уголовного преследования, и иными лицами, исполняющими свой общественный долг по пресечению общественно опасных деяний. Тем не менее, подобная попытка казахстанского законодателя не может быть признана удачной, так как становится неясным - какова правовая природа подобного задержания.

С указанной проблемой весьма тесно переплетаются нормы новой статьи 129 УПК Казахстана 2014 г. «Доставление». Данное нововведение несет в себе положительный потенциал, так как направлено на урегулирование отношений, возникающих при фактическом задержании лица по основаниям, предусмотренным в п.П. 1-4 ч.2 ст. 128 УПК Казахстана 2014 г. Стоит заметить, что данная норма не имеет аналогов в УПК РФ, что порождает полемику в российской науке уголовного процесса $[6,7$,$] , и практические проблемы$ применения задержания. Говоря о доставлении по УПК Казахстана 2014 г. необходимо обратить внимание на определение данного процессуального действия, как меры процессуального принуждения, применяемой на срок не более трех часов в целях выяснения причастности лица к уголовному правонарушению. Сопоставляя цель доставления с целями задержания необходимо констатировать, что доставление в уголовном процессе Казахстана, имея свое специфическое назначение, тем не менее, находится в русле общего предназначения задержания и способствует ему. Специфику доставлению придают следующие моменты: в статье о доставлении законодатель использует термин «лицо», тогда как в других статьях главы 17 - «подозреваемый»; по окончании срока доставления лицу немедленно выдается справка о доставлении, за исключением случаев, когда подтвердилась причастность данного лица к уголовному правонарушению, в этом случае составляется протокол задержания.

В результате анализа ч.ч. 2 и 3 ст.129 УПК Казахстана 2014 г. доставление можно охарактеризовать как некий первоначальный этап собственно задержания, «проверочное задержание», от результатов которого зависит дальнейшее применение ограничивающих свободу мер, составляющих суть задержания. При этом хотелось бы отметить, что, несмотря на прогрессивность регламентации доставления, казахстанский законодатель не избежал определенных противоречий. К ним можно отнести следующее. В ч.ч.1 и 3 ст.129 УПК Казахстана 2014 г. доставление, будучи «мерой процессуального принуждения», противопоставляется «процессуальному задержанию», а в ч.2 этой же статьи говорится о включении срока доставления в общий срок процессуального задержания. В ч.3 ст.129, как представляется, следует более четко обозначить, что доставленное лицо подлежит немедленному освобождению, если его причастность к уголовному правонарушению не подтвердилась либо по окончании срока доставления.

Регламентация порядка задержания в УПК Казахстана 2014 г. в общих чертах совпадает с аналогичной нормой в УПК Казахстана 1997 г. и УПК РФ, однако имеет определенные новшества. Так, в ч.1 ст.131 урегулирован вопрос о порядке разъяснения прав задержанному, неадекватно воспринимающему окружающую его действительность в силу опьянения или иного болезненного состояния. Положительно стоит отметить новеллы ч. 2 ст.131, устанавливающую обязанности должностного лица органа уголовного преследования: а) провести по ходатайству задержанного медицинское освидетельствование для установления общего состояния его здоровья и наличия телесных повреждений, б) указать сведения о состоянии здоровья задержанного в протоколе задержания, в) приложить к протоколу задержания заключение медицинского освидетельствования в случае его проведения. В то же время представляется излишним повторение в ч. 4 ст.131 нормы о предельном сроке задержания без санкции суда на срок более 72 часов, ранее указанной в ч. 5 ст.128.

Говоря о личном обыске подозреваемого по УПК Казахстана 2014 г. обращает на себя внимание указание законодателем непосредственно в статье 132, посвященной данному процессуальному действию, оснований его производства.

Интересной представляется регламентация освобождения задержанного, в ст.133 УПК Казахстана 2014г. Привлекает к себе внимание следующее. Во-первых, наличие дополнительных оснований для освобождения задержанного: отсутствие оснований для применения к задержанному наказания в виде ареста либо выдворения за пределы Республики Казахстан (п.2 ч.1 ст.133) и нарушение порядка задержания (п.3 ч.1 ст.133), вовторых, указание на наличие ответственности руководителя администрации места содержания задержанного за содержание задержанного сверх установленного законом срока (ч. 3 ст.133); в-третьих, закрепление правила о недопустимости в качестве доказательств данных, полученных в результате следственных действий, 
DOI: $10.7256 / 1811-9018.2015 .6 .15323$

При цитировании этой статьи сноска на dоі обязательна

Закон и правопорядок

проведенных с участием незаконно задержанного независимо от времени их проведения (ч.5 ст.133). Данные положения, как представляется, стоит положительно оценить и рассмотреть возможность закрепления аналогичных норм и в УПК РФ.

Отличным от аналогичных положений УПК РФ являются нормы УПК Казахстана 2014 г. о порядке содержания под стражей задержанных и уведомлении родственников задержанного. Напомним, что порядок содержания под стражей задержанных в РФ урегулирован Федеральным законом «О содержании под стражей подозреваемых и обвиняемых в совершении преступлений» от 15 июля 1995 г. №103-Ф3 [8], на который ссылается ст.94 УПК РФ. Ст.134 УПК Казахстана 2014 г. содержит более подробные указания на то, где могут содержаться различные категории задержанных, в том числе и в условиях чрезвычайного положения. На наш взгляд, это верная тенденция, так как содержание под стражей задержанных является мерой процессуального характера и, соответственно, должно регулироваться нормами именно уголовно-процессуального законодательства, а не отдельных нормативных актов. Что касается уведомления родственников подозреваемого о задержании, то взаимосвязанные нормы ч.3 ст.64 и ст.135 УПК Казахстана 2014 г., в отличие от аналогичной нормы УПК РФ (ст.96) не содержат возможности сохранить факт задержания лица в тайне.

Переходя к характеристике мер пресечения, необходимо отметить, что регламентация данных мер в УПК Казахстана 2014 г. осуществлена достаточно подробно и в общих чертах аналогична регламентации данного института в УПК РФ. Тем не менее, отличия имеются как в общих положениях применения мер пресечения, так и при регламентации отдельных мер пресечения, в связи с чем заслуживают особого рассмотрения.

1. Так, при совпадении в общих чертах оснований для избрания мер пресечения, можно выделить возможность избрания мер пресечения к лицу, подозреваемому или обвиняемому в совершении отдельных особо тяжких преступлений, по мотиву одной лишь их опасности.

В качестве новеллы УПК Казахстана 2014 г. позиционируются нормы ч.ч.2-4 ст. 137, закрепившие возможность и условия применения в отношении подозреваемого или обвиняемого наряду с одной из избранных ему мер пресечения, за исключением передачи военнослужащего под наблюдение командования воинской части и содержания под стражей, электронных средств слежения. Применение подобных дополнительных ограничений (а именно так они именуются в наименовании статьи), допустимо при соблюдении ряда различных факто- ров: обеспечения скрытости их ношения, учета мест, посещаемых подозреваемым, обвиняемым, путей их перемещения, возраста, состояния здоровья, семейного положения и образа жизни подозреваемого, обвиняемого. В отличие от рассматриваемых норм казахстанского уголовно-процессуального закона российский УПК предусматривает возможность применения аудиовизуальных, электронных и иных технических средств контроля только в целях осуществления контроля за нахождением подозреваемого или обвиняемого в месте исполнения меры пресечения в виде домашнего ареста и за соблюдением им наложенных судом запретов и (или) ограничений (ч.11 ст.108 УПК РФ). Представляется, что нормы УПК Казахстана 2014 г. позволяют более гибко подойти к решению вопроса обеспечения соблюдения подозреваемым, обвиняемым запретов и ограничений, составляющих существо мер пресечения. Однако при этом казахстанский законодатель, как кажется, допустил определенную терминологическую неточность, закрепив, что «порядок, условия и основания применения электронных средств слежения определяются Правительством Республики Казахстан» [9]. На наш взгляд, условия и основания применения электронных средств слежения, то есть дополнительных ограничений, должны регулироваться нормами уголовно-процессуального законодательства, а не подзаконными нормативными актами, коими являются акты правительства. Нормы УПК РФ, регулируя схожие вопросы применения аудиовизуальных, электронных и иных технических средств контроля в отношении лиц, которым избирается мера пресечения в виде домашнего ареста, устанавливают, что Правительством Российской Федерации определяются лишь перечень и порядок их применения.

Заслуживает одобрения норма ч.2 ст.138 УПК Казахстана 2014 г., устанавливающая недопустимость избрания меры пресечения в виде содержания под стражей в отсутствие оснований, предусмотренных законом, по мотиву одной лишь тяжести преступления, в совершении которого подозревается или обвиняется лицо. При этом думается, что данное правило вместо ст.138, которая регламентирует обстоятельства, учитываемые при избрании любых мер пресечения и установлении дополнительных ограничений, нуждается в закреплении все же в ст.147, регулирующей содержание под стражей.

Освещая применение мер пресечения в отношении подозреваемого по УПК Казахстана 2014 г. стоит обратить внимание на то, что подозреваемый является главной фигурой со стороны защиты на всем протяжении досудебного расследования и становится обвиняемым лишь по его окончании (ст.65). В этой связи приме- 
DOI: $10.7256 / 1811-9018.2015 .6 .15323$

При цитировании этой статьи сноска на doi обязательна

\section{Право и политика 6 (186) 2015}

нении мер пресечения в отношении подозреваемого в уголовном процессе Казахстана с 2015 г. не влечет впоследствии изменения его процессуального статуса, как это происходит в уголовном судопроизводстве России (см. нормы ст.ст.46, 47, 100 УПК РФ). Однако применение каких-либо мер пресечения в отношении подогреваемого налагает на органы досудебного расследования Казахстана обязанность объявить подозреваемому постановление о квалификации содеянного им в течение 10 суток с момента применения данной меры или задержания, если этого не было сделано ранее (см. ст.ст.139 и 140 УПК Казахстана 2014 г.).

Порядок применения мер пресечения по УПК Казахстана 2014 г. также имеет свои специфические черты. Так, несмотря на казалось бы четкое упоминание в ст. 136 о возможности избрания одной из мер пресечения, указанных в ст.137 УПК Казахстана 2014 г., ч.1 ст.140 повторно указывает на недопустимость одновременного применения к подозреваемому или обвиняемому двух и более мер пресечения.

Следующей спецификой порядка избрания мер пресечения в уголовном процессе Казахстана с 2015 г. является то, что наряду с избранием в отношении подозреваемого, обвиняемого, подсудимого любой меры пресечения, кроме содержания под стражей, на этих лиц для обеспечения их надлежащего поведения могут быть возложены определенные обязанности, перечень которых дается в ч.3 ст.140. Большинство из этих обязанностей известны как УПК Казахстана 1997 г. (ст.ст.144, 149), так и УПК Казахстана 2014 г. (ст.ст.141, 146). В качестве новелл УПК Казахстана 2014 г. можно упомянуть обязанности пройти курс лечения от наркотической или алкогольной зависимости (подп. 5) ч.3 ст.140); носить электронные средства слежения (подп. 6) ч.3 ст.140). При этом следует отметить, что в силу ч.2 ст.137 последняя обязанность не может быть возложена также и на военнослужащего, в отношении которого избрана мера пресечения в виде его передачи под наблюдение командования воинской части. Также представляется правильным указание в ч.4 ст.140 УПК Казахстана 2014 г. предписания, что в случае нарушения подозреваемым, обвиняемым условий, избранной ему меры пресечения, она может быть заменена на более строгую. В тоже время неуместным кажется закрепление в этой же части правила о том, что в случае нарушения мер процессуального принуждения, предусмотренных ст.ст. 156, 165 УПК Казахстана 2014 г., в отношении подозреваемого, обвиняемого избирается мера пресечения. Подобная норма, на наш взгляд, вопервых, является избыточной, учитывая ее фактическое закрепление в ч.3 ст.156 и ч.7 ст.165 УПК Казахстана 2014 г., а во-вторых, она более органично вписалась бы в качестве ч.3 ст.136 УПК Казахстана 2014 г.

Вполне обоснованным можно признать, что отмена или изменение мер пресечения, санкционированных, примененных прокурором, избранных по его указанию в ходе досудебного производства по уголовному делу, в том числе залога, домашнего ареста, содержания под стражей, производится только с согласия прокурора (ч.ч. 3, 4 ст.153 УПК Казахстана 2014 г.).

С точки зрения логики представляется более правильной позиция законодателя в УПК Казахстана 2014 г., поместившего нормы о попечении и присмотре за имуществом содержащегося под стражей задержанного, обвиняемого или подсудимого (ст.154) в главу, регулирующую меры пресечения, а не общие условия предварительного расследования, как это реализовано в УПК РФ.

2. Рассматривая отдельные меры пресечения и порядок их избрания и применения можно выделить следующие особенности нового уголовно-процессуального законодательства Казахстана в сравнении с российским УПК:

- в отношении личного поручительства:

а) обращает на себя внимание количество поручителей - их должно быть не менее двух (ч.1 ст.142);

б) указывается наименование процессуального документа, свидетельствующего о принятии на себя обязательств поручителем - подписка (ч.3 ст.142);

в) поручитель имеет право в любой момент производства по делу отказаться от принятого на себя поручительства (ч.4 ст.142);

г) в случае отказа поручителя от принятого на себя поручительства вопрос о замене меры пресечения должен быть решен в течение 48 часов с момента такого отказа (ч.4 ст.142), что является новеллой УПК Казахстана 2014 г. в сравнении с УПК Казахстана 1997 г.

На наш взгляд, регламентация личного поручительства в УПК Казахстана 2014 г. более прогрессивна в сравнении с УПК РФ, но не лишена отдельных недостатков: 1) более правильным будет указание на необходимость решения вопроса о замене меры пресечения из-за отказа поручителя от поручительства в течение 48 часов не с момента отказа, а с момента получения этого отказа лицом, избравшим данную меру пресечения; 2) при отказе поручителя от поручительства не предусмотрена альтернатива в виде замены такого поручителя на другое заслуживающее доверие лицо - вместо этого необходимо сразу решать вопрос об избрании иной меры пресечения, но отказ поручителя 
DOI: $10.7256 / 1811-9018.2015 .6 .15323$

При цитировании этой статьи сноска на dоі обязательна

Закон и правопорядок

может быть обусловлен и иными, не связанными с поведением или личностью подозреваемого обстоятельствами, например выезд поручителя за границу на длительный срок и т.п.;

- в отношении наблюдения командования воинской части за подозреваемым, обвиняемым:

a) не указывается, что данная мера пресечения избирается лишь с согласия подозреваемого или обвиняемого;

б) об установлении наблюдения командование воинской части в письменном виде уведомляет орган, избравший эту меру пресечения (ч.2 ст.143);

в) указывается на то, что лица, виновные в невыполнении возложенных на них обязанностей по наблюдению, несут предусмотренную законом ответственность (ч.4 ст.143);

г) закрепляется правило о том, что в период действия данной меры пресечения не допускается привлечение подозреваемого, обвиняемого к боевому дежурству, несению боевой или караульной службы, службы в составе гарнизонного наряда или суточного наряда части (подразделения) (ч.5 ст.143).

- в отношении залога:

a) в случае внесения залога иным, отличным от денежных средств, имуществом обязанность доказывания ценности предмета залога и отсутствие его обременений возлагаются на залогодателя (ч.1 ст.145);

б) устанавливается, что данная мера пресечения не применяется в отношении подозреваемых, обвиняемых в совершении особо тяжких преступлений, а также в определенных уголовно-процессуальным законом случаях, связываемых законодателем с общественной опасностью преступления (преступлений), в совершении которых подозревается или обвиняется лицо, либо с поведением подозреваемого или обвиняемого в ходе расследования или рассмотрения уголовного дела (ч.9 ст.148);

в) предусматривается возможность избрания данной меры пресечения не только судом, но и следственным судьей, а также иными органами с санкции прокурора (ч.2 ст.145);

г) минимальные размеры залога дифференцируются не только в зависимости от тяжести преступлений, в совершении которых подозревается или обвиняется лицо, но и в зависимости от формы умысла (ч.3 ст.145);

д) имеется возможность установления суммы залога ниже установленных законом минимальных размеров в отношении определенных категорий лиц, например, имеющих нетрудоспособных иждивенцев, являющихся несовершеннолетними, пенсионерами, относящихся к социально уязвимым слоям населения, получающих социальные выплаты за счет бюджета, а также не имеющих постоянных источников дохода (ч.3 ст.145);

е) избирая в качестве меры пресечения залог в отношении задержанного подозреваемого, суд не продлевает срок задержания (не более чем на 72 часа как это предусмотрено в ч.7 ст.106 УПК РФ), а применяет меру пресечения в виде содержания под стражей или домашний арест до фактического внесения залога, но не более чем на 10 суток (ч.5 ст.145, ч.7 ст.148);

ж) закрепляется обязанность следственного судьи, разрешающего вопрос об избрании меры пресечения в виде содержания под стражей, определить сумму залога, достаточного для обеспечения выполнения подозреваемым, обвиняемым обязанностей, предусмотренных ст.140 УПК Казахстана 2014 г., а также указать, какие именно из этих обязанностей будут возложены на подозреваемого, обвиняемого в случае внесения залога, последствия их неисполнения, обоснованность избрания размера залога, а также возможность его применения (ч.8 ст.145).

3) с учетом предыдущего положения предусматривается, что воспользоваться залогом как альтернативой содержанию под стражей в разрешенных законом случаях подозреваемый, обвиняемый вправе независимо от волеизъявления органа, ведущего уголовный процесс, после фактического внесения установленного в постановлении залога (ч. ст.145);

и) предусмотрено, что залог подлежит немедленному возвращению залогодателю при условии, что подозреваемый, обвиняемый не нарушали возложенные на них обязанности в случаях: 1) когда в отношении подозреваемого, обвиняемого избрана более строгая мера пресечения; 2) вынесения приговора; 3) вынесения постановления о прекращении производства по уголовному делу; 4) обращения залогодателя с письменным заявлением о невозможности в дальнейшем обеспечивать выполнение лицом, за которое он внес залог, возложенных на него обязанностей (ч.ч.9, 10 ст.145).

к) закрепляется возможность при наличии гражданского иска, процессуальных издержек и необходимости иных имущественных взысканий по ходатайству прокурора обратить взыскание на предмет залога или его часть, внесенного самим подозреваемым, обвиняемым, а на предмет залога, внесенного иными лицами - только с их согласия (ч.9 ст.145);

л) устанавливается правило о взыскании сумм, затраченных на обеспечение сохранности залога, с залогодателя (ч.12 ст.145).

Резюмируя особенности регламентации залога в УПК Казахстана 2014г. стоит отметить, что часть из них 
DOI: $10.7256 / 1811-9018.2015 .6 .15323$

При цитировании этой статьи сноска на доі обязательна

\section{Право и политика $6(186) \cdot 2015$}

может быть включена после соответствующего обсуждения в статью 106 УПК РФ в виде соответствующих частей. В частности, к ним можно отнести правила о неприменении залога к обвиняемым, подозреваемым в совершении особо тяжких преступлений, о возможности снижения размера залога, об установлении возможности альтернативного применения залога при избрании мер пресечения в виде домашнего ареста или заключения под стражу. В то же время имеется и ряд неясностей, например в каких случаях залог применяется с санкции прокурора, а в каких - с санкции следственного судьи;

- в отношении домашнего ареста:

а) установлено, что решение об избрании домашнего ареста принимается по тем же основаниям и в том же порядке, что и решение об избрании содержания под стражей (ч.1 ст.146);

б) перечень ограничений, которые могут быть установлены судом подозреваемому, обвиняемому при избрании в отношении него меры пресечения в виде домашнего ареста, несколько шире и содержит, как представляется, не столько собственно ограничения, сколько определенные обязанности арестованного для облегчения контроля за ним со стороны соответствующих государственных органов (ч.2 ст.146);

в) говоря о контроле за выполнением арестованным возложенных на него судом обязанностей, часто происходит использование различных терминов-синонимов («контроль», «надзор»), что не способствует однозначному толкованию и применению данных нормативных предписаний (п.п. 4), 5) ч.2 ст.146).

г) установлен четкий порядок осуществления надзора за поведением арестованного в месте его пребывания: обозначены способы, периодичность и время осуществления проверок (ч.2 ст.146).

- в отношении содержания под стражей:

а) название данной меры пресечения «содержание под стражей» стало точнее отражать его сущность, нежели прежнее «арест» (ст.147);

б) сама регламентация применения данной меры осуществляется сразу несколькими статьями УПК Казахстана 2015г. - ст.ст.147-150;

в) было установлено, что данная мера пресечения, как правило, применяется к подозреваемому, обвиняемому или подсудимому в совершении преступления, за которое предусмотрено наказание в виде лишения свободы на срок не менее пяти лет, и лишь при определенных условиях - в отношении иных подозреваемых, обвиняемых или подсудимых (ч.1 ст.147);

г) перечень вышеуказанных условий наряду с из- вестными российскому УПК, в частности содержит: подозрение в совершении преступления в составе организованной группы или преступного сообщества (преступной организации); наличие у лица судимости за ранее совершенное тяжкое или особо тяжкое преступление; наличие данных о продолжении лицом преступной деятельности (ч.1 ст.147);

д) применению данной меры пресечения непременно предшествует задержание подозреваемого (ч.1 ст.128, ч.2 ст.147);

е) данная мера вполне может быть использована как альтернатива домашнему аресту и залогу (ч. 5 ст. 145 , ч.1 ст.146, ч.7 ст.148);

ж) установлено, что данная мера пресечения избирается только с санкции следственного судьи районного и приравненного к нему суда, а при отмене или изменении его решения - областного и приравненного к нему суда (ч.1 ст.148);

3) направление следственному судье ходатайства о санкционировании применения данной меры пресечения, предшествует получение органом досудебного расследования согласия прокурора, которому для решения данного вопроса предоставлено всего шесть часов (ч. 2, 4 ст.147);

и) решение прокурора о поддержании ходатайства органа уголовного преследования или об отказе в этом принимается им только после обязательного изучения материалов дела, в рамках которого прокурор вправе допросить подозреваемого, обвиняемого (ч.3 ст.147);

к) в случае отказа прокурора от подержания ходатайства о санкционировании применения данной меры пресечения подозреваемый подлежит безусловному освобождению из-под стражи (ч.3 ст.147);

л) при решении вопроса о поддержании ходатайства органа досудебного расследования о санкционировании содержания под стражей подозреваемого прокурор вправе направить ходатайство следственному судье о санкционировании иной меры пресечения (ч.3 ст.147);

м) процедура рассмотрения ходатайства о санкционировании содержания под стражей сконструирована так, что решение следственным судьей принимается в срок не позже чем за четыре часа до истечения срока задержания (ч. 4 ст.147, ч.2 ст.148);

н) рассмотрение ходатайства о санкционировании содержания под стражей возможно в отсутствие подозреваемого при условии, если он объявлен в розыск или находится вне пределов Республики Казахстан и уклоняется от явки в орган, ведущий уголовный процесс, будучи надлежащим образом уведомленным о времени и месте судебного заседания (ч.4 ст.147); 
о) следственный судья, не усмотрев достаточных оснований для санкционирования содержания под стражей на срок два месяца, вправе санкционировать эту меру пресечения и на меньший срок, например, на 10 суток (ч.7 ст.147);

п) постановление следственного судьи о санкционировании или об отказе в санкционировании содержания под стражей направляется в том числе и начальнику учреждения места содержания под стражей (ч.10 ст.147);

р) специально оговариваются места содержания подозреваемых под стражей - следственные изоляторы (ст.149), либо в случаях, когда доставка в следственный изолятор невозможна из-за отдаленности или отсутствия надлежащих путей сообщения, или необходимости проведения следственных действий или рассмотрения дела судом - изоляторы временного содержания (военнослужащие - на гауптвахте), но не более 30 суток (ст.150);

с) устанавливается предельный срок содержания под стражей в ходе досудебного производства по уголовному делу с учетом его продления в определенных случаях - не более 18 месяцев (ч.ч.4, 5 ст.151);

т) детально регулируется порядок подачи ходатайств о продлении сроков содержания под стражей, их рассмотрения прокурорами различных уровней, следственным судьей с установлением четких временных рамок принятия всех процессуальных решений (ч.ч.2-4, 6-8, 10-12 ст.151, ст. 152);

у) специально оговаривается, что срок содержания под стражей исчисляется с момента заключения подозреваемого под стражу до уведомления его об окончании производства следственных действий и разъяснении права ознакомиться с материалами уголовного дела, однако при этом регламентируется возможность как нахождения под стражей подозреваемого в период ознакомления его и защитника с материалами уголовного дела, так и продление его сроков (ч.6, 7 ст.152);

ф) закрепляется, что срок содержания под стражей лица, выданного для уголовного преследования иностранным государством, исчисляется с момента его прибытия на территорию Казахстана (ч.10 ст.152).

Изучив регламентацию иных мер процессуального принуждения в УПК Казахстана 2014г., следует сделать следующие выводы:

- данные меры могут применяться как вместо, так и наряду с мерами пресечения (ч.1 ст.155);

- перечень иных мер процессуального принуждения пополнился еще одной мерой - запретом на приближение (ст.165);
- регламентация конкретных мер принуждения, предусмотренных главой 19 УПК Казахстана 2014г., осуществлена более детально в сравнении с аналогичными нормами УПК РФ, в частности это касается оснований, принятия решения о применении, последствий несоблюдения данных мер;

- ряд нормативных положений главы 19 УПК Казахстана 2014г. являются спорными, например: ходатайство о санкционировании временного отстранения от должности рассматривается единолично следственным судьей без участия сторон, при этом предусмотрена возможность обжалования и опротестования данного постановления (ч.5, 6 ст.158); допускается внесудебное ограничение прав владельцев при наложении ареста на имущество (в случаях, не терпящих отлагательства, с согласия прокурора допускается установить временное ограничение на распоряжение имуществом на срок не более десяти суток - ч.1 ст.161, в случаях, когда имеются основания полагать, что имущество, подлежащее аресту, может быть сокрыто или утрачено, возможно приостановить совершение сделок и иных операций с имуществом либо оно может быть изъято до получения санкции суда с уведомлением прокурора и суда в течение двадцати четырех часов - ч.9 ст.161);

- запрет на приближение (ст.165) как иная мера процессуального принуждения имеет несколько целей: во-первых, обеспечение предусмотренного УПК порядка расследования, судебного разбирательства по уголовным делам, и надлежащего исполнения приговора, а во-вторых, обеспечение безопасности потерпевшего или иного лица подлежащего защите;

- учитывая серьезность ограничения отдельных прав подозреваемого иными мерами процессуального принуждения, по степени строгости не уступающими мирам пресечения, предусматривается судебное и прокурорское санкционирование их применения;

- несоблюдение требований иных мер процессуального принуждения с большей степенью вероятности повлечет применение к подозреваемому, обвиняемому одной из мер пресечения.

Завершая рассмотрение мер процессуального принуждения по УПК Казахстана 2014 г., стоит обратить внимание, что казахстанский УПК также детально подошел и к применению мер принуждения, необходимых для экстрадиции: отдельные статьи посвящены экстрадиционному аресту, временному содержанию под стражей и т.д. (ст.ст.584-589).

Подобная юридическая техника, когда регулирование того или иного института уголовного процесса исчерпывающим образом осуществляется группой рядом 
DOI: $10.7256 / 1811-9018.2015 .6 .15323$

При цитировании этой статьи сноска на dоі обязательна

\section{Право и политика $6(186) \cdot 2015$}

расположенных статей, является весьма удобной для правоприменителя - не надо искать взаимосвязанные статьи. В то же время излишняя детализация делает нормативный акт менее абстрактным и компактным.
Многие положения УПК Казахстана 2014 г. стоит охарактеризовать как достаточно прогрессивные и заслуживающие проработки на предмет их включения в УПК РФ.

\section{Библиография:}

1. У Головно-процессуальный кодекс Республики Казахстан от 4 июля 2014 года № 231-V (с изменениями и дополнениями по состоянию на 07.11.2014 г.) // URL: http://online.zakon.kz/Document/?doc_id=31575852\#pos=177;6 (дата обращения 04.05.2015).

2. Уголовно-процессуальный кодекс Республики Казахстан от 13 декабря 1997 года №206-I. Алматы: Юрист, 2009. 08 с.

3. Уголовно-процессуальный кодекс Российской Федерации от 18 декабря 2001 г. №174-ФЗ (с изменениями и дополнениями по состоянию на 30.03.2015 г.) // URL: http://base.garant.ru/12125178/ (дата обращения 04.05.2015).

4. В Татарстане предъявлены обвинения бывшим полицейским по делу о смерти задержанного // URL: http://www.tatarinform.ru/news/2012/03/14/308057/ (дата обращения 04.05.2015).

5. Уголовный кодекс Российской Федерации от 13 июня 1996 г. №63-Ф3 (с изменениями и дополнениями по состоянию на 30.03.2015 г.) // URL: http://base.garant.ru/10108000/ (дата обращения 04.05.2015).

6. Абдрахманов Р.С. Проблемы уголовно-процессуального задержания // Законность. - 2003. - № 3. - С. 21-22.

7. Ц Цоколова О.И. Фактическое задержание // Законность. - 2006. - № 3. - С. 25-28.

8. Гайнов И.Д. К вопросу о правомерности задержания подозреваемых до возбуждения уголовного дела // Научные труды Казанского юридического института МВД России: вып. 9 / Под ред. к.и.н., доцента С.Н. Миронова. - Казань: Казанский юридический институт МВД России, 2009. С. 4-10.

9. Федеральный закон от 15 июля 1995 г. №103-Ф3 «О содержании под стражей подозреваемых и обвиняемых в совершении преступлений» (с изменениями и дополнениями по состоянию на 22 декабря 2014 г.) // URL: http://base.garant.ru/1305540/ (дата обращения 04.05.2015).

10. Постановление Правительства Республики Казахстан от 24 декабря 2014 года № 1369 «Об утверждении Правил, условий и оснований применения электронных средств слежения» // URL: http://online.zakon.kz/Document/?doc_id=31648720\&doc_ id2=31648720\#pos=1;-39\&sub_id2=100\&sel_link=1004391166 (дата обращения 04.05.2015).

11. Выонг Т.Л., Чан Т.Т. Виды и характеристика уголовно-процессуального задержания в праве Социалистической Республики Вьетнам // Журнал зарубежного законодательства и сравнительного правоведения / Journal of foreighn legislation and comparative law. - 2014. - 5. - C. 884-886.

12. Быков В.М. Новый закон о домашнем аресте подозреваемого или обвиняемого: научный комментарий // Право и политика. - 2012. - №3. - С. 481-486.

13. Быков В.М. Закон о домашнем аресте подозреваемого или обвиняемого: научный комментарий // Административное и муниципальное право. - 2012. - №3. - С. 14-20.

\section{References (transliterated):}

1. Abdrakhmanov R.S. Problemy ugolovno-protsessual'nogo zaderzhaniya // Zakonnost'. - 2003. - № 3. - S. 21-22.

2. Tsokolova O.I. Fakticheskoe zaderzhanie // Zakonnost'. - 2006. - № 3. - S. 25-28.

3. Gainov I.D. K voprosu o pravomernosti zaderzhaniya podozrevaemykh do vozbuzhdeniya ugolovnogo dela // Nauchnye trudy Kazanskogo yuridicheskogo instituta MVD Rossii: vyp. 9 / Pod red. k.i.n., dotsenta S.N. Mironova. - Kazan': Kazanskii yuridicheskii institut MVD Rossii, 2009. S. 4-10.

4. Vyong T.L., Chan T.T. Vidy i kharakteristika ugolovno-protsessual'nogo zaderzhaniya v prave Sotsialisticheskoi Respubliki V'etnam // Zhurnal zarubezhnogo zakonodatel'stva i sravnitel'nogo pravovedeniya / Journal of foreighn legislation and comparative law. - 2014. - 5. - C. 884-886.

5. Bykov V.M. Novyi zakon o domashnem areste podozrevaemogo ili obvinyaemogo: nauchnyi kommentarii // Pravo i politika. 2012. - №3. - C. 481-486.

6. Bykov V.M. Zakon o domashnem areste podozrevaemogo ili obvinyaemogo: nauchnyi kommentarii // Administrativnoe i munitsipal'noe pravo. - 2012. - №3. - C. 14-20. 